\title{
Determinants of dividend payout ratio: evidence from Indonesian manufacturing companies
}

\author{
Dessy Widyawati ${ }^{1}$ and Astiwi Indriani ${ }^{2}$ \\ 1,2Department of Management, Faculty of Economics and Business, Universitas Diponegoro, Indonesia
}

\begin{abstract}
The purpose of this study is to investigate and analyze the relationship between return on assets, growth sales, debt to equity ratio, lagged dividend to dividend payout ratio and size as control variable. Data collected from manufacturing industries in Indonesian Stock Exchange 2011-2017. The method of this study is ordinary least square regression. The results of this study shows that return on assets and lagged dividend have positive impact to dividend payout ratio. Growth sales has insignificance negative relationship to dividend payout ratio. Debt to equity ratio has positive relationship to dividend payout ratio and has insignificance sign.
\end{abstract}

\section{INTRODUCTION}

The main purpose of investors buying manufacturing stock is to make a profit. The profits obtained by investors from buying stocks are capital gains and dividends that annually distributed by the company. Capital gain itself can be interpreted by the return that investor get from the increase in share price that he purchases from the initial price (Kasmir, 2014). At the same time, dividends are the profit distribution by the company to shareholders.

Dividends have crucial role to maintain good relation of investor to companies, because dividends are evidence that a company is able to generate profits precisely from the investors' point of view. The evidence shows that manufacturing company in Indonesia increased the amount payed dividend from year to year. The company manages to continuously distribute dividends to shareholders so the investors invest to their company. Therefore, ratio of the proportion of dividends to profits that generated by companies frequently becomes consideration of investor to invest. This ratio is called the dividend payout ratio. The greater the proportion of dividends distributed by a company, the greater the proportion of profits distributed as dividends, and the smaller proportion of retained profits that a company used to make investments and support operational activities.

Various factors could influence a companies to determine the dividend payout ratio to be distributed to shareholders.
Profitability generated by the company mention to be the factor that could determinie dividend payout ratio. (Baker, Powell, \& Veit, 2002) they found that the pattern of dividends distributed in the past and expectations of current and future earnings were one of the main factors determining dividend policy of a companies. Companies that are more profitable could provide higher dividends than less profitable companies.

ROA (return on assets) is ratio that used to measure of profitability to examine the relationship on dividend policy (Kumar \& Ranjani, 2018), (Amidu and Abor, 2006), (John \& Muthusamy, 2010). ROA positively affects dividend policy by Amidu \& Abor, (2006); Kumar \& Ranjani, (2018) who conduct research on manufacturing and service companies. High ratio of ROA will be captured by investors as a good signal that the company can manage its assets and generate profits well. Increased profits are certainly a stimulus for investors to invest their capital in the company. This finding is in accordance with the cash flowtheory mentioned that companies that have a high ROA will also have high cash flow, so the company would prefer to distribute dividends instead of using cash flow to invest in investments that tend to be risky. But research conducted by John \& Muthusamy (2010) has showed different result that return on assets has negatively affected dividend payout ratio. So there is a gap between the previous study conducted.

Growth sales are measure used by companies to see the value of investment 
opportunity. The greater the proportion of dividends distributed to shareholders, the greater it will reduce the proportion of profits that will be used for investment and business expansion, so that company tend to decrease their dividend payment (D'Souza, 2010). (Benlemlih, 2018) compared the effect of growth sales to the dividend payout ratio in companies with high and low CSR (corporate social responsibility). Benlemih obtained results that growth sales had a significant negative effect on dividend payout ratios in high and low CSR companies. Similar results were also obtained from research conducted by Amidu \& Abor (2006)); Wicaksono \& Nasir (2014). This finding is supported by concept of the life cycle proposed by Modigliani, stated that countries and individuals will prepare future pension funds through the growth sales obtained (Modigliani, 1985). Different results stated by Gill et al (2010), they did obtained the results that growth sales have a positive effect to dividend payout ratio but there is no significant effect on growth sales. These different results cause inconsistency of research results or often called the research gap.

The main purpose of calculating debt to equity ratio (DER) is to find out how much amount of equity reserved by the company to pay all its debts, so that if the debt to equity ratio is getting higher, it shows that the company has a small amount of reserves to meet its obligations. This statement related to the distribution of dividends, the greater DER, the company will reduce distributed dividend to obtain greater reserves so the company could meet its obligations. Rahmawati, Saerang, \& Rate (2014) and Apriliani \& Natalylova, (2017) also stated that debt to equity ratio is one of the factors that influence dividend payout ratio. Pecking order theory supports this finding, where companies prefer internal funding using retained earnings and through loans bank rather than using external equity funding through selling shares to investors by distributing dividends that are considered to have higher risk (Zameer, 2013). In contrast research conducted by Apriliani \& Natalylova (2017), shows that debt to equity ratio did not have a significant negative effect on dividend payout ratio.
The amount of dividend distributed by company from year to year is also considered as one of the factors that influence dividend policy. The amount of dividends distributed is a stimulus for investors to invest their money, the amount of dividends also indirectly indicates that a company can generate profits well. Companies that recognize this should manage to maintain the amount of distributed dividends from year to year and tend to increase it. The statement is supported by research conducted by Damayanti, Marwati, \& Widayanti, (2017). The theory of signal also stated that the company tries as much as possible to give a signal to investors and it is able to generate good profits each year through dividends. The distribution of dividends from the previous year (lagged dividends) which indicates an increase is evidence that the company has good future prospects. But in the other hand research conducted by Benlemlih (2018) showed that dividend payout ratio has negative effect to divided payout ratio.

Size of a company is often associated with factors that affect the dividend payout ratio distributed by the company. Size in this research used as a controlled variable to isolate the dependent variable from the influence of variables that are not included in the research and could interfere the research results. According to Fama \& French (2001), size has a close relationship with the dividend payout ratio. They said that companies with large sizes will be more likely to pay higher dividends and vice versa. Size has also been used as a controlled variable in dividend research from previous studies conducted by Adjaoud \& Ben-Amar (2010), Benlemlih (2018).

Dividends distributed by manufacturing companies also continue to show an upward trend, this is shown by Graph 1 which summarizes the distribution of cash dividends by manufacturing companies during 20112017. This rising trend indicates a positive signal captured by investors because it shows the commitment of the companies to increasing amount of dividend distributed. This finding seems interesting to researchers in conducting this research. 


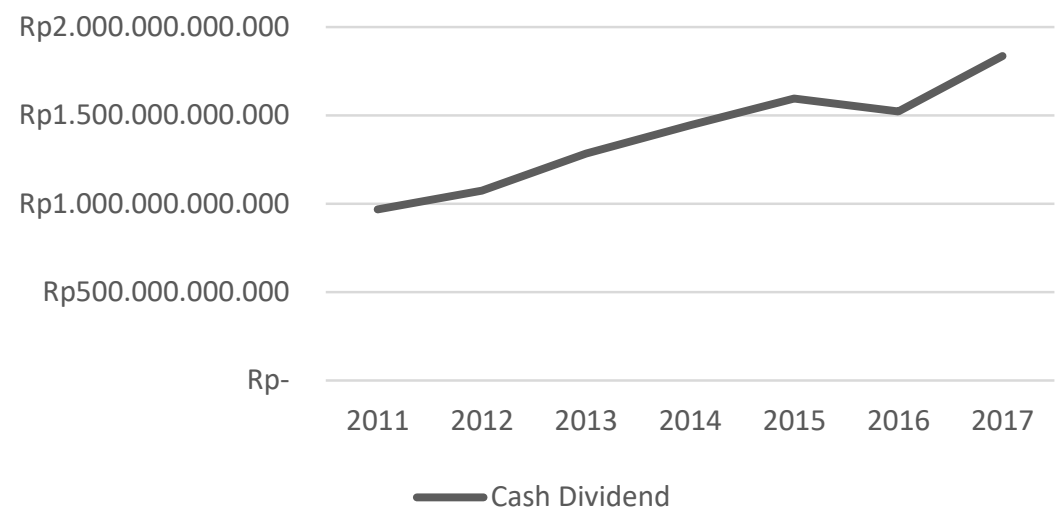

Figure 1.

Cash dividend graph manufacturing companies in Indonesia

The purpose of this study is to analyze the impact of return on assets, growth sales, debt to equity ratio, lagged dividend on dividend payout ratio using Size as a controlled variable.

\section{LITERATURE REVIEW AND HYPOTHESES DEVELOPMENT}

\section{Dividend payout ratio}

Dividend payout ratio is considered by investors as a comparison and a benchmark of how much the company distributes their earning to investors. This statement is in accordance with Gordon (1963) that investors are more interested in dividends distributed by companies than compared to capital gains that investors will get in the future which is full of uncertainties. From this statement, companies made consideration to share a large proportion of dividends in order to attract investors. According to the bird in the hand theory, an investor will be quieter if he receives dividends that are regulary distributed by the company, rather than obtaining a large amount of capital gain in the future that full of uncertainty.

\section{Relationship between return on assets and dividend payout ratio}

Profitability obtained by a company is one of factors that become consideration of dividend distribution by company. Profitability measurement often used by researcher is return on assets. The concept of free cash flow stated that companies with excess funds will use their money to invest in lower NPVs

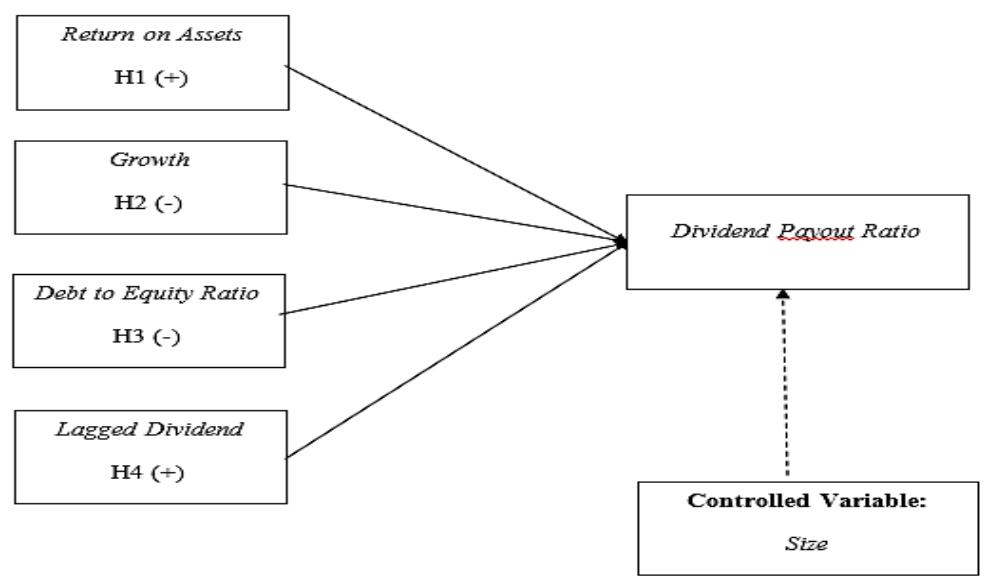

Figure 2.

Conceptual model 
that are very risky. In order to reduce the risk, the shareholders decided to distribute the excess funds as dividends so that it could reduce the amount of excess funds managed by management as well as a stimulus for investors in the capital market to invest more fund in the company (Zameer, 2013). Several studies stated that return on assets has a significant positive effect on dividend payout ratio (Benlemlih, 2018; Zaman, 2018; Amidu \& Abor, 2006; Apriliani \& Natalylova, 2017; Samrotun, 2015; Wicaksono \& Nasir, 2014; Gill, Biger, \& Tibrewala, 2010). Based on the explanation above, we proposed hypothesis as follows:

H1: Return on assets has positive relationship to dividend payout ratio in manufacturing company.

\section{Relationship between growth sales and dividend payout ratio}

Dividend distribution decision is created in the process of discussing and deciding on financial and investment plans (Gill et al., 2010). The greater the proportion of dividends distributed to shareholders, the greater in reducing proportion of profits that will be used for investment and business (D'Souza, 2010). Benlemlih compares the effect of growth on the company's dividend payout ratio from high and low CSR.

Growth sales also has a significant negative relationship on dividend payout ratios in high CSR and low CSR (Benlemlih, 2018). Similar results were obtained from research conducted by Amidu \& Abor, (2006) who conducted research on twenty companies listed on the Ghana stock exchange and Wicaksono \& Nasir (2014) who conducted a dividend payout ratio study on manufacturing companies listed on the Indonesian Stock Exchange from 2011-2013. The concept of life cycle said growing companies will tend to be used their fund for saving, expansion and, preparing for an uncertain future, so their distributed dividends tend to be lower. Based on the explanation above, hypothesis could be proposed as follows:

H2: Growth sales has negative relationship to dividend payout ratio in manufacturing company.

\section{Relationship between debt to equity ratio and dividend payout ratio}

The main purpose to calculate debt to equity ratio (DER) is to find out how much amount of equity reserved by the company to pay all its debts, so that if the debt to equity ratio is getting higher, it shows that the company has a small amount of reserves to meet its obligations. This statement related to the distribution of dividends, the greater DER, the company will reduce distributed dividend to obtain greater reserves so the company could meet its obligations. Rahmawati, Saerang, \& Rate (2014) and Apriliani \& Natalylova, (2017) also revealed that debt to equity ratio is one of the factors that affect dividend payout ratio. Pecking order theory supports this finding, where companies prefer internal funding using retained earnings and through loans bank rather than using external equity funding through selling shares to investors by distributing dividends that are considered to have higher risk (Zameer, 2013). When the company has high level of debt to equity ratio, imply that the company has to pay off the loan and the loan interest. So company wil be prefer to use their income to pay off the loan and interest rather than distributed dividend to shareholder, so it will be decrease the amount of dividend payout ratio. Based on the explanation above, hypothesis can be proposed as follows:

H3: Debt to equity ratio has negative relationship to dividend payout ratio manufacturing company.

\section{Relationship between lagged dividend and dividend payout ratio}

The amount of dividend distributed by company from year to year is also considered as one of the factors that affects dividend policy. The amount of dividends distributed is a stimulus for investors to invest their money, the amount of dividends also indirectly indicates that a company can generate profits well. Companies that recognize this should try to maintain the amount of distributed dividends from year to year and even tend to increase it. The statement is supported by research conducted by Damayanti, Marwati, \& Widayanti, (2017). The theory of signal also said the company tries as much as possible to give a signal to investors that the company is able to generate good profits each year through dividends. If the distribution of 
dividends from the previous year (lagged dividends) shows an increase, it could be conclude that the company has good future prospects. In addition, according to the bird in the hand theory, an investor will be quieter if he receives dividends that are distributed by the company regularly, rather than obtaining a large capital gain in the future. Based on this theory, the management will try as much as possible to secure investor funds to remain in the company by regularly providing dividends and continuing increase the amount of dividend distribution. Based on the explanation, hypothesis can be proposed as follows:

H4: Lagged dividend has positive relationship to dividend payout ratio manufacturing company.

\section{METHODS}

There are four independent variables used in this study, namely return on assets, growth sales, debt to equity ratio and lagged dividend using one dependent variable, namely dividend payout ratio and one controlled variable, namely size.

Population used in this research is manufactured industries in Indonesian Stock Exchange 2011-2017. Purposive sampling is the sampling method that been used in this study, and acquired result 20 samples manufacturing companies that been tested.

\section{Measurement}

In our study, dividend payout ratio was measured using the formula developed by Gill et al. (2010).

$D P R=\frac{\text { Yearly Dividend }}{\text { Net Income after Tax }}$

Return on assets was measured using the formula refer to Samrotun (2015) as follow:

$R O A=\frac{\text { Net Income after Tax }}{\text { Total Assets }}$
Growth sales is the company's growth sales from year to year. This variable was measured using formula developed by Gill et al. (2010) as follow

Growth $=\frac{\left(\operatorname{Net~Sales}_{(t)}-\operatorname{NetSales}_{(t-1)}\right)}{\operatorname{NetSales}_{(t-1)}}$

Debt to equity ratio is a ratio used to measure the ratio of company debt to how much equity it has. The formulas to measure Debt to Equity Ratio refered to Samrotun (2015) as follow:

$D E R=\frac{\text { Total Liabilities }}{\text { Total Equities }}$

Lagged Dividends are dividends that distributed by the company in the previous year and measured using formula developed by Ahmed \& Javid (2008) as follow:

Lagged Dividend $=\frac{\text { Dividend Per Share }_{(t-1)}}{\text { Market Sharet }_{(t-1)}}$

Size is the size of the company as measured by total assets. According to Samrotun (2015) size may use proxy as follow:

$S=\ln ($ Total Assets $)$

\section{Research model}

There are two models in this study, model 1 (without controlled variable), formulated:

$$
\begin{aligned}
\text { PAYOUTit }= & \alpha+\beta 1 \text { ROAit }+\beta 2 \text { GROWTHit } \\
& +\beta 3 \text { DER }+\beta 4 \text { LAGDIVit }+\varepsilon
\end{aligned}
$$

and model 2 (using controlled variable) formulated as follow:

$$
\begin{aligned}
\text { PAYOUTit }= & +\beta 1 \text { ROAit }+\beta 2 \text { GROWTHit }+ \\
& \beta 3 \text { DER }+\beta 4 \text { LAGDIVit }+\beta 5 \\
& \text { CONTROLit }+\varepsilon
\end{aligned}
$$


Table 1.

T-test (model 1)

\begin{tabular}{|c|c|c|c|c|c|}
\hline \multirow[t]{2}{*}{ Model } & \multicolumn{2}{|c|}{$\begin{array}{l}\text { Unstandardized } \\
\text { Coefficients }\end{array}$} & \multirow{2}{*}{$\begin{array}{l}\text { Standardized } \\
\text { Coefficients } \\
\text { Beta }\end{array}$} & \multirow[t]{2}{*}{$T$} & \multirow[t]{2}{*}{ Sig. } \\
\hline & B & Std. & & & \\
\hline 1 (Constant) & .072 & .039 & & 1.864 & .065 \\
\hline ROA & 1.412 & .150 & .603 & 9.411 & .000 \\
\hline GROWTH & -.095 & .052 & -.112 & -1.829 & .070 \\
\hline DER & .023 & .014 & .099 & 1.586 & .115 \\
\hline LAGDIV & .060 & .014 & .279 & 4.356 & .000 \\
\hline
\end{tabular}

Table 2.

T-test (model 2)

\begin{tabular}{lllllll}
\hline Model & \multicolumn{2}{l}{$\begin{array}{l}\text { Unstandardized } \\
\text { Coefficients }\end{array}$} & \multicolumn{2}{l}{$\begin{array}{l}\text { Standardized } \\
\text { Coefficients }\end{array}$} & Sig. \\
\cline { 2 - 5 } & B & Std. Error & Beta & & \\
\hline 1 & (Constant) & -1.260 & .242 & & -5.210 & .000 \\
ROA & 1.207 & .119 & .579 & 10.130 .000 \\
GROWTH & -.125 & .044 & -.160 & -2.865 & .005 \\
DER & .020 & .013 & .089 & 1.561 & .121 \\
LAGDIV & .068 & .012 & .327 & 5.692 & .000 \\
& SIZE & .046 & .008 & .309 & 5.594 & .000 \\
\hline
\end{tabular}

Table 3.

Goodness of fit (model 1)

\begin{tabular}{llllll}
\hline Model & $\mathbf{R}$ & R Square & $\begin{array}{l}\text { Adjusted R } \\
\text { Square }\end{array}$ & $\begin{array}{l}\text { Std. Error of the Durbin- } \\
\text { Estimate }\end{array}$ & Watson \\
\hline 1 & $.762 a$ & .581 & .567 & .17284 & 1.926 \\
\hline
\end{tabular}

Table 4.

Goodness of fit (model 2)

\begin{tabular}{llllll}
\hline Model & $\mathbf{R}$ & R Square & $\begin{array}{l}\text { Adjusted R } \\
\text { Square }\end{array}$ & $\begin{array}{l}\text { Std. Error of the Durbin- } \\
\text { Estimate }\end{array}$ & $\begin{array}{l}\text { Watson } \\
\text { Wats }\end{array}$ \\
\hline 1 & $.798 \mathrm{a}$ & .636 & .621 & .16189 & 2.058 \\
\hline Source: SPSS Output & & & & &
\end{tabular}

\section{RESULTS AND DISCUSSION}

The assessment result of return on assets, growth sales, debt to equity ratio, lagged dividend to dividend payout ratio shows on Table 1 and 2.

Based on the results of the analysis in model 2, the formed regression equations are: ROA has a significant positive effect on dividend payout ratio, when ROA rises $1 \%$ will increase dividend payout ratio by 1,207 unit. GROWTH has a significant negative effect on dividend payout ratio, when GROWTH rises 1\% will reduce dividend payout ratio by 0.125 units. DER has an insignificant positive effect on dividend payout ratio, when DER rises $1 \%$ will increase dividend payout ratio by 0.020 units. LAGDIV has a significant positive effect on dividend payout ratio, when LAGDIV rises $1 \%$ will increase the dividend payout ratio by 0.068 units.

\section{Goodness of fit model test}

Goodness of fit testing is useful to find out how close the relationship between the independent variables and the dependent variable. This goodness of fit value is explained by the adjusted $\mathrm{R}$ square number by table 3 and 4 : 
Table 5.

F-test (model 1)

\begin{tabular}{llllll}
\hline Model & Sum of Squares & Df & Mean Square & F & Sig. \\
\hline 1 Regression & 4.810 & 4 & 1.203 & 40.255 & $.000 \mathrm{~b}$ \\
Residual & 3.465 & 116 & .030 & & \\
Total & 8.276 & 120 & & & \\
\hline
\end{tabular}

Table 6.

F-test (model 2)

\begin{tabular}{|c|c|c|c|c|c|}
\hline Model & Sum of Squares & Df & Mean Square & $\mathbf{F}$ & Sig. \\
\hline 1 Regression & 5.366 & 5 & 1.073 & 40.945 & $.000 b$ \\
\hline Residual & 3.067 & 117 & .026 & & \\
\hline Total & 8.432 & 122 & & & \\
\hline
\end{tabular}

Adjusted R-Squre value shows an increase from model 1 to model 2 , so it can be concluded that after adding the controlled variables, the model can explain better variation of the dependent variable to the variation of the independent variables. In this study, model 2 has an Adjusted R Square value of 0.621 so $62.1 \%$ of the variation of the dependent variable can be explained by the variation of the independent variables. Subsequently, $37.9 \%$ is explained by other factors.

\section{F-test}

The $F$ test is used to observe the simultaneous relationship between the dependent variable namely PAYOUT with the independent variables ROA, GROWTH, DER, LAGDIV and SIZE:

Based on the hypothesis testing tables, model 1 and model 2 produce $p$ values of $0,000<0.05$ (significance value) simultaneously. This indicates that there is significant relationship (together) return on assets (ROA), growth sales (GROWTH), debt to equity ratio (DER), lagged dividend (LAGDIV) and size (SIZE) to dividend payout ratio (PAYOUT).

\section{Relationship between return on assets and dividend payout ratio}

The result of return on assets on dividend payout ratio indicates that return on assets has a significant positive effect on dividend payout ratio. This is in accordance with research conducted by Kumar \& Ranjani (2018) and Amidu \& Abor (2006) which shows that return on assets has significantly positive relationship on dividend payout ratio. The support of this study was obtained from the concept of free cash flow mentioned that if a company has a high return on assets, this will certainly increase the amount of free cash flow. Shareholders prefer to use free cash flow for distribution of dividends so that they can attract investor funds that can be used for business processes.

Companies that has high level of return on assets will increase the amount of free cash flow holding by the company. shareholders prefer to use this free cash flow for distribution of dividends so that investor will be investing in their company. So, when return on assets increase will be affect an increase in dividend payout ratio.

\section{Relationship between growth sales and dividend payout ratio}

The result shows that growth sales has a significant negative effect on dividend payout ratio. This indicates if growth sales increase, the dividend payout ratio will decrease. The greater the proportion of dividends distributed to shareholders, the greater will reduce the proportion of profits that will be used for investment and business expansion (D'Souza, 2010). Benlemlih compares the relationship of growth on the company dividend payout in high and low CSR. Growth sales also have significant negative relationship on dividend payout ratios in high CSR and low CSR (Benlemlih, 2018). Similar results were obtained from research conducted by Amidu and Abor (2006) who conducted research on twenty companies listed on the Ghana stock exchange. In addition, Wicaksono \& Nasir (2014) who conducted a dividend payout ratio study on manufacturing companies listed on the Indonesia Stock Exchange from 2011-2013. Concept of life cycle said growing companies will tend to be used to their growth for saving, 
expansion and preparing for an uncertainty in the future.

Companies with high growth will look further into the future, so they attempt to save the growth they have obtained to expand and prepare reserves for future uncertainty. In the other hand, the companies with zero growth or companies that only has small amount of increasing levels of income will tend to focus on securing the company's position at the time by attracting investors to obtain adequate supply of funds through the distribution of dividends.

So, when company has high level of sales growth, the excess income from growth will be used as saving and expansion fund rather than being distributed as dividend.

\section{Relationship between debt to equity ratio and dividend payout ratio}

The results show that the debt to equity ratio has insignificant positive relationship on dividend payout ratio. This indicates if debt to equity rises it will increase the dividend payout ratio and vice versa. These results are consistent with the results obtained by Samrotun (2015) and Damayanti et al (2017) which states that there is a positive relationship between debt to equity ratio against dividend payout ratio.

Insignificant results were obtained because there was a fairly high range in the debt to equity ratio data, namely the minimum value of 0.08 (ratio) and a maximum value of 3.60 (ratio). This high range of data generates insignificant research results. The theory that supports this finding is risk theory (Hawley, 1893) where companies with high debt to equity ratio values have high risks dealed with running their business because the amount of debt is greater than the equity. This high risk is taken by the company with the intention to expand in it. The expansion carried out by this company will increase its production capacity so that it can fulfill more demand from the market for its products which will then increase the company's net income. This increase in net income will make the company distributed greater dividend, assuming the change in the percentage of distributed dividend by the company is higher than the percentage change in net income, then the dividend payout ratio will increase.

\section{Relationship between lagged dividend and dividend payout ratio}

The results show that lagged dividend has a significant positive effect on dividend payout ratio. This indicates if the lagged dividend increases, it will increase the dividend payout ratio. Lagged dividend or the amount of dividend distribution from last year is also considered as one of the factors that influence companies to determine dividend policy. The amount of dividends distributed is a stimulus for investors to invest their money, the amount of dividends also indirectly indicates that a company can generate profits well. Companies that recognize this statement try to maintain the amount of dividends payment from year to year and even tend to increase it. This statement is in accordance with research conducted by Damayanti et al who conducted research on 133 companies listing on the Indonesia Stock Exchange in 2011-2015 (Damayanti et al., 2017). In addition, several studies also indicate lagged dividend has positive relationship to the dividend payout ratio, (Adu-Boanyah et al., 2013). Another study is Adjaoud (2010) who conduct research on the Ghana Stock Exchange. The theory of signals stated that the company tries as much as possible to give a signal to investors that the company is able to generate good profits through dividend distribution. The increasing distribution of dividends from the previous year (lagged dividend) shows that the company has good prospects.

\section{Relationship between controlled variable and dividend payout ratio}

Size in this research was used as a controlled variable to isolate the dependent variable from the influence of variables that are not included in the research that could interfere the research results. Size measured through the company's total assets. the test results show that size has a positive relationship on dividend payout ratio. This indicates if Size increases, it will be followed by an increase in dividend payout ratio and vice versa.

The result of Model 2 (using controlled variable) shows better results. It is proven by 3 variables that have significant relationship, namely return on assets, growth sales, lagged dividends, which previously on Model 1 only 2 variables have a significant relationship. Simultaneous test (F Test) 
shows a significance level at 0.000 indicates that return on assets, growth sales, debt to equity ratio, lagged dividend and size as controlled variables together affected dividend payout ratio. The adjusted R-Square value shows an increase to $62.1 \%$, which means that $62.1 \%$ of the dependent variable variation can be explained by the variation of independent variable.

So when the lagged dividend increase the company tend to maintaining the amount of dividend paid even increase it because the company knew that lagged dividend does matter to investor preference to invested their fund, therefore the dividend payout ratio will be increase too.

\section{CONCLUSION}

The purpose of this study to investigate and analyze the relationship of return on assets, growth sales, dept to equity ratio, lagged dividend to dividend payout ratio and size as controlled variable, study conduct in manufacturing industries in Indonesian Stock Exchange 2011-2017

Return on assets (ROA) has positive significant relationship on dividend payout ratio. Therefore, the conclusion is that $\mathrm{H} 1$ is supported as well. Growth sales (GROWTH) has negatively significant effect on dividend payout ratio. So, the conclusion is $\mathrm{H} 2$ is supported. Debt to equity ratio (DER) has positively insignificant relationship on the dividend payout ratio. It could be concluded that $\mathrm{H} 3$ is not supported. Lagged dividend (LAGDIV) has positive significant relationship on dividend payout ratio. The conclusion is $\mathrm{H} 4$ is supported.

The limitation of this study are R-Square research on the model shows in the figure is quite low, that is only 0.621 , which means the model can only describe $62.1 \%$ of the variation of independent variables and $37.9 \%$ are still explained by other factors. Only a few manufacturing companies in Indonesia distribute dividends regularly for a period of 7 years.

The further studies will be conducted using broader objects and add more variables such as assets composition and liabilities index (Athari, Adaoglu, \& Bektas ; 2016).

\section{REFERENCES}

Adjaoud, F., \& Ben-Amar, W. (2010). Corporate governance and dividend policy:
Shareholders' protection or expropriation? Journal of Business Finance and Accounting, 37(5-6), 648$667 . \quad$ https://doi.org/10.1111/j.14685957.2010.02192.x

Adu-Boanyah, E. (2013). Determinants of dividend payout policy of some selected manufacturing firms listed on the Ghana Stock Exchange ., 4(5), 49-61.

Ahmed, H., \& Javid, A. Y. (2008). Dynamics and determinants of dividend policy in Pakistan (evidence from Karachi stock exchange non-financial listed firms). Munich Personal RePEc Arcive, /(37342). Retrieved from https://core.ac.uk/download/pdf/12031629 .pdf

Amidu, M., \& Abor, J. (2006). Determinants of dividend payout ratios in Ghana. Journal of Risk Finance, 7(2), 136-145. https://doi.org/10.1108/152659406106485 80

Apriliani, A., \& Natalylova, K. (2017). Faktor-faktor yang mempengaruhi kebijakan dividen pada perusahaan manufaktur di bursa efek indonesi. Jurnal Bisnis Dan Akutansi, 19(1a), 49-57.

Benlemlih, M. (2018). Corporate Social Responsibility and Dividend Policy. Research in International Business and Finance.

https://doi.org/https://doi.org/10.1016/j.rib af.2018.07.005

D’Souza, J. (2010). Agency Cost, Market Risk , Investment Opportunities and Dividend Policy - An International Perspective. Managerial Finance, 25(6), 35-43.

Damayanti, R., Marwati, F. S., \& Widayanti, R. (2017). Analisa Kebijakan Dividend Berdasarkan Teori Lintner. Jurnal Ekonomi Dan Bisnis, Vol 1 No 2(September 2017), 183-194. https://doi.org/10.22236/agregat_vol1/is2 pp183-194

Fama, E. F., \& French, K. R. (2001). Disappearing Dividends: Changing Firm Characteristics or Lower Propensity to Pay? Journal of Applied Corporate Finance, 14.1(Spring 2001).

https://doi.org/doi.org/10.1111/j.17456622.2001.tb00321.x

Gill, A., Biger, N., \& Tibrewala, R. (2010). Determinants of Dividend Payout Ratios: Evidence from United States. The Open Business Journal, 3, 8-14. https://doi.org/10.2174/187491510100301 0008

Gordon, M. J. (1963). Optimal Investment and Financing Policy, 264-272. 
Hawley, F. B. (1893). The Risk Theory of Profit.

John, S. F., \& Muthusamy, K. (2010). Leverage, Growth and Profitability as Determinants of Dividend Payout Ratio-Evidence from Indian Paper Industry. Asian Journal of Business Management Studies, 1(1), 2630. https://doi.org/10.1182/blood-200907-233718. The

Kasmir. (2014). Analisis Laporan Keuangan (1st ed.). Jakarta: PT Raja Grafindo Persada.

Kumar, S., \& Ranjani, K. S. (2018). Dividend Behaviour of Indian-listed Manufacturing and Service Sector Firms. Global Business Review. https://doi.org/10.1177/097215091775386 3

May, E. (2018). Saham Paling Top 2017 \& Peluangnya di 2018.

Modigliani, F. (1985). Life Cycle, Individual Thirft and The Wealth of Nations. Economic Science, (1985), 150-171.

Rahmawati, N. D., Saerang, I. S., \& Rate, P. Van. (2014). Kinerja Keuangan Pengaruhnya terhadap Kebijakan Dividen pada Perusahaan BUMN di Bursa Efek Indonesia. Jurnal Ekonomi Dan Bisnis, 2(2), 1306-1317. https://doi.org/10.1016/j.jcrysgro.2005.06. 058
Samrotun, Y. C. (2015). Yuli Chomsatu Samrotun Dosen FE Universitas Islam Batik ( UNIBA ) Surakarta size terhadap kebijakan dividen pada perusahaan Industri Barang Konsumsi yang terdaftar di Bursa Efek Indonesia ( BEI ) selama periode tahun 2011-2014 .., 13(01), 92103.

Wicaksono, S., \& Nasir, M. (2014). Analisis faktorfaktor yang mempengaruhi kebijakan dividen pada perusahaan manufaktur yang terdaftar di BEl tahun 2011-2013. Diponegoro Journal Of Accounting, 3, 113.

WorldBank. (2017). Manufacturing Value Added GDP.

Zaman, D. R. (2018). Effect of Financial Performance on Dividend Policy in Manufacturing Companies in Indonesia Stock Exchage, (30 January 2018).

Zameer, H. S. R. S. I. ;Umair A. (2013). Determinants of dividend policy: A case of banking sector in Jordan. International Journal of Economic Research, 13(4), 1411-1422.

https://doi.org/10.5829/idosi.mejsr.2013.1 8.3.12200 